\title{
The Impact of Tax Planning in Industrial Public Joint Stock Companies upon the Performance of the Industrial Companies Listed in the Amman Stock Exchange Market
}

\author{
Khalid Ali Ahmad Alduneibat ${ }^{1}$, Mohammad abdallah fayad altawalbeh ${ }^{1} \&$ Firas Na'el Rawhi Hashem $^{1}$ \\ ${ }^{1}$ Lecturer, Tafilah Technical University, Jordan \\ Correspondence: Firas Na'el Rawhi Hashem, Lecturer, Tafilah Technical University, Jordan
}

Received: February 6, 2017

Accepted: February 20, 2017

Online Published: February 28, 2017

doi:10.5430/afr.v6n2p12

URL: https://doi.org/10.5430/afr.v6n2p12

\begin{abstract}
The purpose of this current study is seeking to shed a light on the issue of tax planning which is considered to be one of the most significant topic that are related to the matters of tax. It has become something significant to investigate and identify the impact of tax planning in industrial public joint stock companies upon the performance of the Industrial companies listed in the Amman stock exchange market. The method of this study adopted the analytical descriptive approach the population of the current study includes financial managers who were working in Jordanian industrial public joint stock companies. The total number of those companies is 66 companies in Jordan. The result of the study there is an impact for conducting tax planning in industrial public joint stock companies upon the performance of the Industrial companies listed in the Amman stock exchange market the recommendation of the study has proposed the following the researcher recommended exerting much efforts to raise awareness of companies' managers and employees about the legal consequences of tax evasion.
\end{abstract}

Keywords: Tax Planning, Industrial Companies, Performance, Stock exchange

\section{Introduction}

Financial and tax reports are characterized with having their own disclosure rules for disclosing expenses and revenue. According to the financial accounting rules, the value of the revenue is verified upon ensuring that the standards of disclosing revenues are met and the same applies to the incurred expenses. The desire to enter a record of the real value of the revenue varies among companies because such desires have an impact upon the tax rate that shall be set. For instance, the greater the value of the revenue is, the grater the tax rate would be (Chen et al., 2007). Companies do not take marginal tax rate into consideration when making additional decisions. Many researchers have concluded that the companies which suffer from high tax rates- that have exceeded the maximum limit -suffer from having many debts that are due to be paid (Zarai, 2013).

Additionally, studies have found that high levels of debt (either as a result of high tax rates or due to managerial decisions) negatively impact the competitiveness of a firm in the market (Checherita-Westphal \& Rother, 2012; Riasi, 2015). Which means that in long term, firms that are highly leveraged, will suffer from revenue losses (Ansari \& Riasi, 2016; Aghdaie et al., 2012)

Tax planning is considered to be one of the financial instruments that many funders depend on in funding their enterprises and companies and it's a major element of administrative and financial planning. Furthermore, tax planning is considered an ongoing policy which is not used during a certain period of time only. In addition this process takes into consideration all the administrative decisions related to taxes. It also takes into consideration the strategies used for reducing the burden of incurred taxes to the minimum limit as much as possible. This process doesn't aim at evading taxes or reducing them directly. In fact, it aims at making a plan to reduce the real value of the relevant tax. That is done through postponing the process of paying it in order to benefit from the time value of money. For instance, the due tax may be paid through several installments or may be postponed to cover some expenses as much as possible (Ibrahim, 2012).

Thus, the current study aimed at identifying the impact of tax planning in industrial public joint stock companies upon the performance of the Industrial companies listed in the Amman stock exchange market. 


\section{Statement of the Problem and the Study's Elements}

There is a high tax rate incurred by industrial public joint stock companies that exceed the tax rates incurred by other sectors. This former influential rate amount to $14 \%$ of the income subjected to tax. Such rate is considered one of the most significant and huge burdens incurred by the Jordanian public joint stock companies. (http://www.istd.gov.jo/ISTD/Arabic/Legislations/LatestLaws).

The Jordanian sector of industrial public joint stock companies is considered to be one of the most significant sectors that participate in achieving economic stability. Thus, those companies must plan their financial and investment decisions in a way that can increase their profits and enhance their financial positions. That shall be done in the aim of achieving their objectives and guaranteeing their survival in the market that is highly competitive.

Tax planning has a major significant role in influencing the performance of any organization that is subjected to tax deductions. Thus, managers and employees who work in companies must be aware about the significance of such planning and take all of its aspects into consideration in order to look like as attempts made for evading taxes.

Based on the aforementioned information, the problem of the current study is represented in seeking to measure and identify the impact of tax planning in industrial public joint stock companies upon the performance of the Industrial companies listed in the Amman stock exchange market

\section{The Problem of the Current Study can be Represented in the Following Two Questions}

1) - What is the impact of tax planning in industrial public joint stock companies upon the performance of the Industrial companies listed in the Amman stock exchange market?

2) - Is there any statistical significant difference between the respondents' attitudes towards the impact of tax planning in industrial public joint stock companies upon the performance of the Industrial companies listed in the Amman stock exchange market - which can be attributed to one of the following variables:-educational level or years of experience)?

\section{The Study's Significance}

The practical significance of the current studs arises from seeking to shed a light on the issue of tax planning which is considered to be one of the most significant topic that are related to the matters of tax. It has become something significant to investigate and identify the impact of tax planning in industrial public joint stock companies upon the performance of the Industrial companies listed in the Amman stock exchange market. Whereas the theoretical significance of the current study arises from the significance of conducting tax planning processes in enterprises and projects. For instance, it is highly significant to be aware about the reality of the tax planning in industrial public joint stock companies in order to fill a gap in the relevant literature.

\section{The Study's Hypotheses}

\subsection{The First Hypothesis}

Ho: There is no impact for tax planning in industrial public joint stock companies upon the performance of the Industrial companies listed in the Amman stock exchange market.

\subsection{The Second Hypothesis}

Ho: There is no statistical significant difference between the respondents' attitudes towards the impact of tax planning in industrial public joint stock companies upon the performance of the Industrial companies listed in the Amman stock exchange market which can be attributed to one of the following variables:- educational level or years of experience.

\section{The Study's Methodology}

The current study adopted the analytical descriptive approach. The researcher has set hypotheses to be tested under this exploratory research. These hypotheses were tested through distributing the study's instrument to the selected sample.

\subsection{The Study's Population}

The population of the current study includes financial managers who were working in Jordanian industrial public joint stock companies. The total number of those companies is 66 companies in Jordan. (https://www.sdc.com.jo/english/index.php?option=com_public\&member_cat=900\&member_sub_cat=4).

The researchers distributed one questionnaire to each company. However, he retrieved60 forms only and they were valid to be analyzed statistically. Thus, the ratio of such retrieval is (90.9\%) 


\subsection{Data Collection Methods}

The researchers collected the relevant data through using the following sources of data:

1) - Secondary sources: Such sources include books, periodicals, studies, articles, and the information that is available on the World Wide Web (the internet).

2) - Primary sources: (which are represented in the study's instrument): Such sources include the study's questionnaire which the researchers has designed in order to distribute its forms to the respondents.

\section{The Study's Theoretical Framework}

\subsection{Tax Planning}

There is no doubt that tax is a financial obligation that must be paid without obtaining any direct benefit. However, its benefits shall be reflected upon individuals in an indirect manner. In case the tax started to become a burden upon the one who shall pay it, then he shall seek for methods to reduce tax and facilitate the process of paying it. However, the tax payer shall do that in a legitimate manner in order to avoid any liability and punishment by enforcing him to pay it. Companies adopt tax planning process as a legitimate process for reducing the tax and facilitating the process of paying it.

\subsection{Definition of the Expression "Tax Planning"}

It refers to the attempts carried out for reducing tax and gaining benefits from the relevant laws, internal statute, tax explanatory and operational instructions, periodical books and the pamphlets published by the management that deal with matter related to tax. Thus, tax planning is a logical analytical process carried out for proposing financial plan that aims at obtaining tax benefits that are in align with the financial objectives. The purpose of tax planning is represented in finding methods that can obtain financial benefits through reducing the tax liabilities (Note 1).

Tax planning processes differ from one legislation to another. For instance, some tax legislations do not acknowledge loan interests and consider them one of the costs that are not subjected to deduction. Thus, there wouldn't be any difference between funding by loans and self-funding.

In addition, if the tax legislation did not acknowledge all the methods of fixed assets deprecation that are stated in the accounting standard No. 10 that is related to fixed assets and its deprecation, then there shall be no room for tax planning in such a case.

\subsection{Elements of Tax Planning}

1) - Planning to eliminate the tax, if that was legally permitted through tax exemptions.

2)- Benefitting from the costs that are subjected to tax deduction and using cost items that are subjected to deduction instead of using non-cost items, such as using funding by loans instead of self-funding.

3) - Postponing the date on which the tax shall be due to be paid as much as possible. That is done through acknowledging all the costs and expenses that have been incurred during the first few years of implementation the project, especially in the cases of exempting the project from taxes for certain periods of time through using methods of evaluating inventory or pricing it.

4) - Benefitting from all the tax exemptions that are stated in the tax law and the relevant laws.

5) - Choosing the appropriate legal form for the relevant enterprise.

The tax planning process is considered as an ongoing process which use is not restricted to a certain period of time or to addressing a certain item financially. In fact, such process must be adopted in a constant manner. It also takes all the administrative decisions (related to tax strategies) into its consideration. Such tax strategies include the following:

1) - Conducting a comparison between purchasing fixed assets and renting them and identifying which one is better in relation to tax matters

2) - Conducting a comparison between two sale methods; paying in cash and paying through long term installments

3) - Setting a certain policy for distributing profits and keeping possession of legal and optional reserves.

4) - Purchasing assets through loans, renting, and financial lease.

5)- Restructuring the expenses of salaries and rewards and allowances paid to the members of the board of directors especially in the companies that are located in free zones in order to reduce the tax rates imposed upon them 
6)-Posting the losses entry of the years that were not chosen as a sample to be analyzed - for the following years as being verified losses.

Thus, tax planning is a concept that do not refer in any way to tax evasion. In fact, it is a concept that depends much on setting procedures and policies that permit managers and allow them to reduce taxes imposed upon their companies to the minimum limit as much as possible. Such procedures and policies enable managers to benefit from the laws' loopholes and from the facilities that are stated in laws and organizational rules (Note 2).

\section{Distinguishing between Tax Planning, Avoidance, and Evasion}

\begin{tabular}{lll}
\hline No. & Concept & Definition \\
\hline 1 & tax planning & $\begin{array}{l}\text { When the funder organizes his affairs in a way that enables him to gain benefits from } \\
\text { the tax law in a way that can increase the revenues after deducting the specified tax. In } \\
\text { other words, tax planning is a method that seeks using legitimate methods in order to } \\
\text { benefit from tax exemptions or tax reduction. An example to that is benefiting from the } \\
\text { granted tax exemptions or posting the cash flow entry to other following years in order } \\
\text { to subject such amounts of money to lower tax ratios }\end{array}$ \\
\hline 2 & Tax avoidance & $\begin{array}{l}\text { When the funder uses legitimate methods for reducing the tax rates that are due to be } \\
\text { paid by him without resorting to any planed processes. }\end{array}$ \\
\hline 3 & Tax evasion & $\begin{array}{l}\text { When the funder uses illegitimate methods for evading paying the tax. Such act is } \\
\text { considered to be an illegitimate act that violates the law. It is done through submitting } \\
\end{array}$ \\
& $\begin{array}{l}\text { incorrect data for evading paying the tax. Such act results in subjecting its doer to } \\
\text { financial penalties and sometimes criminal penalties. Such penalties may be doubled if } \\
\text { committing such act was repeated }\end{array}$
\end{tabular}

The process of tax planning includes the implantation of various strategies in order to reduce the amounts of money paid as taxes during a certain period. It also aims at reducing the tax liability to provide more money for covering the expenses, carrying out investments and achieving development. In this manner, tax planning participates in finding new sources of working capital. There are two kinds of basic rules that govern the process of tax planning. The first kind of such rules is represented in entering a record of the costs of depreciation when purchasing machines and equipment before the end of the fiscal year. That can participate in reducing the amounts of money paid as paid for that fiscal year.

Second, companies must postpone the payment of taxes when that is permitted and possible. Postponing paying the taxes can help those companies in benefitting from these amounts of money without any interest rates. However, such companies pay their taxes in the data on which these taxes become due (Note 3).

In addition, tax planning aims to set plans for various things. Such things include: selecting certain accounting methods to be a policy for estimating inventory, choosing the appropriate time for purchasing equipment and disclosing the amounts of earnings. Such things include preserving the same levels of earnings through applying the agreements of preventing double taxation and applying the exchange rates in case there wasn't any agreement made about the law for neutral prices to be adopted between contractual parties. Such things also include conducting constant modifications upon the relationship between the concerned parties (such as changing the party's title from being an associate company to being an affiliated company). Such things also include establishing service branches, centers and offices that represent the company to benefit from the advantages of tax planning in a constant manner.

\section{Strategies of tax Planning (Note 4)}

1) - Strategies for obtaining tax cuts

2) - Strategies for obtaining tax credits

3) - Strategies for posting the records of the real value of income, profits, and losses to the following fiscal years to protect the company's money from the high tax rates. Tax strategies also include strategies for postponing paying the tax and strategies to benefit from the tax rates that are more convenient (through using exchange rates between affiliated companies or making use from the period of tax exemption).

4) - Strategies for reducing the burden of being subjected to capital profits.

Those strategies are implemented through implementing certain mechanisms. Such strategies may include postponing the acknowledgement of earnings in order to subject them to lower tax rates. Such strategies may also include raising deductions (deductible costs and exemptions) through the making use from the flexible forms of laws 
and their loopholes, or the flexible accounting standards. Such strategies may include raising the tax deduction value during the period of tax exemptions and benefiting from the agreements of preventing double taxation. Such strategies also include exchanging assets instead of selling them - especially for affiliated companies - and entering foreign markets through representing offices instead of establishing branches. They may also include launching investments in foreign countries or using the exchange rates to exchange goods and services. Thus, the process of tax planning is a very complicated process and is faced with numerous risks on the level of global and Arab companies (Note 5). Based on the aforementioned information, companies resort to tax planning to avoid being committed to paying big amounts of money as taxes. Thus, tax planning processes aim at saving amounts of money instead of paying them as a tax to achieve long and short terms benefits.

Tax planning is considered one of the financial instruments that tax payers in enterprises and companies depend on when proposing the administrative and financial plans. For instance, adopting tax planning strategies and policies help funders in reducing the amounts of money that are due to be paid as a tax. Tax planning has an impact upon the financial performance of companies and affects their survival in the business market that is highly competitive. Thus, Ibrahim (2012) chose a group of financial indicators that reflect the financial performance of joint stock companies. That is because good tax planning would be reflected positively upon the companies' financial coverage and would double the wealth of the companies' owners due to saving money that should have been paid as a tax. Then, that shall be reflected positively upon the wealth of stakeholders and increase it. For instance, if the company saved the money that should have been paid as a tax, that shall be reflected positively upon the dividends and increase them and increase shareholders' equity. Whereas, Daheya (2010) aimed to shed a light upon the problem and challenges that are faced by the Sudanese institutions due to the lack of attention given to strategic plans or not proposing them. This study also aimed to identify the significance of applying strategic plans through adopting a case study approach. Such approach is considered a significant approach in descriptive studies. The study's problem was investigated through referring to secondary data resources that are represented in books, references, documents, and periodicals. The study's also made use from primary data resources that are represented in the instruments of the study; the questionnaire and interview. The study concluded several results and proposed several recommendations. As for the results that were concluded by Daheya (2010), they are represented in the following ones:

1) - There is a significant impact for the lack of attention given to strategic planning and not having specific objectives in the strategic plans of the taxation chamber.

2) - There is a significant negative impact for the lack of attention given to analyzing the internal environment upon the strategic plans of the taxation chamber. Such lack of attention shall lead to having inadequate knowledge about the aspects of weakness and strength of taxation chamber's strategic plans

3) - There is a significant negative impact for the lack of attention given to analyzing the external environment upon the strategic planning in the taxation chamber. Such lack of attention shall lead to having inadequate knowledge about the opportunities available to the taxation chamber's strategic plans and the threats that are facing them.

4) - There is a significant negative impact for the not fully exploiting the available energy resources upon the taxation chamber's strategic plans

5) - There is a significant positive impact for adopting the value added tax system upon the taxation chamber's strategic plans

Khwaira (2004) conducted a study that aimed at identifying the degree of using tax planning and its elements in the companies that are listed in the Palestinian stock exchange market for the aim of reducing their tax burdens through using legitimate methods. According to Khwaira (2004), the elements of tax planning are represented in the following:

1) - Implementing tax plans through letting the companies listed in the Palestinian stock exchange market benefit from the benefits that have been granted to them from the income tax act

2)-Implementing tax plans through letting the companies listed in the Palestinian stock exchange market benefit from the benefits that have been granted to them from the investment promotion act

3) - Implementing tax plans through letting the companies listed in the Palestinian stock exchange market practice financial, administrative and accounting procedures and policies.

In addition, the study of Khwaira (2004) was concerned with identifying the relationship between the company's tax burden and its tax planning through examining the various elements of tax planning. The study also aimed at identifying the variance between the arithmetic mean of the impact of using each element of the aforementioned tax 
elements. The study of Khwaira (2004) concluded that the study's respondents truly believed that companies seek to benefit from the benefits granted to them by the income tax act. It was also concluded that there is a strong relationship between the listed companies 'that enjoy the benefits granted to them through the income tax act and the reduction of their tax burdens. Most of the respondents believed that companies are benefitting a little from the benefits granted to them by the investment promotion act.

Ala'mouri (2001) aimed at analyzing the process of tax planning and its impacts upon the reduction of the tax burdens imposed upon the profits of industrial joint stock companies in Yemen. The study concluded that industrial joint stock companies that are located in Yemen have obtained benefits from the ones granted to them through the investment promotion act with a ratio of $73 \%$. It also concluded that those companies have obtained benefits from the ones granted to them by practicing the policies of financial, administrative and accounting policies and procedures by a ratio of $61 \%$. The study also concluded that those companies have benefited from the income tax act by a ratio of $68 \%$.Thus, it noticed that the extent of benefiting from those vary. Furthermore, those companies benefited from the free zones act by a ratio of $36.2 \%$ which is a low ratio. The study also showed that those companies have benefited from the elements of tax planning with a moderate ratio of $59.6 \%$ in reducing their tax burdens. The study also concluded that there is a statistically significant positive impact for using the elements of tax planning upon companies. The significance level of this impact is 0.001 which is less than the significance level of 0.05 . The study also concluded that there is no statistically significant positive impact for the free zones act upon such companies. The significance level of this impact is 0.833 which exceeds the significance level of 0.05 .In addition, the study also concluded that industrial joint stock companies in Yemen benefit from the tax planning elements in reducing their tax burdens more than the industrial joint stock companies of limited liability.

Kawor \& Kportorgbi (2012) aimed at identifying the of performance level of companies' tax planning. In addition, their study also aimed at investigating the relationship between tax planning and companies' market performance. The researchers applied this study upon twenty two (22) non-financial companies that are listed in Ghana stock exchange market during the period of ( $2000-2012$ ). Their results indicated that companies' tendency to participate in intensive tax planning activities decreases when tax authorities keep the imposed tax in lower rates. Secondly, tax planning has a neutral impact upon companies' performance. The latter result is inconsistent with the studies that have concluded that the money saved through tax planning process shall be reflected positively upon investors' earnings. Thus, it can be concluded that investors must establish systems that can guarantee having positive impacts for conducting tax planning activities upon their earnings.

Edwards et al., (2013) aimed at investigating the relationship between financial constraints-whether on the macroeconomic or private company level -and the money saved by a tax planning activities as a source of company's internal funds. It is expected that there are factors that encourage companies to take measures to increase their internal funds through resorting to conducting tax planning activities and measuring financial constraints on the basis of macroeconomic measures (using the gross domestic product and imposing restrictions upon bank loans). Such factors encourage companies to measure the indicators of financial constraint. These factors include: increasing financial constraints, and providing external funds. It can be noticed that the company that is facing financial obstacles post an entry of low value of cash flow in order to avoid facing high tax rates. That requires having a good understanding for the impact of financial constraints and the way they can lead to tax evasion. It also requires having an understanding for the interaction between macroeconomic forces and tax evasion on the company level. That shall participate in reducing the fiscal deficit.

The study of Zarai (2013) aimed at conducting a full investigation for the relationship between companies' tax planning and growth of endogenous debts. This study proposes a tax framework for investigating the growth of endogenous debts. It was concluded by Zarai (2013) that return on assets and net operational losses are the main determinants of tax planning in companies. The researcher believed that the company's fixed characteristics do not constitute the whole determinants of its tax planning.

Nor Shaipah (2012) dealt with the relationship between tax planning, corporate governance and the value of shareholders' equity in the joint stock market. Nor Shaipah (2012) has also concluded that tax planning participates much in enhancing the company's financial performance, provided that the company has applied the governance rules well. Tax planning is implemented in order to avoid having contradiction in the data submitted by managers and internal auditors. The study recommended giving more attention to the application of tax planning strategies in order to improve and enhance the financial performance of the facility and raise the market value of its stocks.

Khaoula \& Ali (2012) aimed to identify the impact of the characteristics of the board of directors upon companies' tax planning in developing countries. Results of the study of Khaoula \& Ali (2012) showed that duality and diversity 
in the board of directors' positions have a major impact upon the tax planning process. For instance, it was concluded that duality in positions has a negative relationship with tax rates. In addition, it was also concluded that diversity in the board of directors' positions has a positive relationship with tax rates. In addition, it was also concluded that there is no relationship between the board's size, its independent members and company's tax planning.

Christopher (2012) investigated briefly the tax incentives that are published annually by the tax authorities in the United Kingdom (UK). Such incentives are published to view the tax benefits provided by the United Kingdom (UK) government for the facilities located in it to benefit from. Such benefits are related to tax exemptions, and credit. The study also aimed at measuring the financial performance level of the companies that are listed in the stock exchange market and were benefitting from the tax incentives provided by the UK government. The study concluded that the companies that were benefiting from the tax incentives are the ones which stocks are traded the most.

Chen et al. (2007) aimed to investigate the impact of tax planning and earning management upon the information content of the book income and the income that is subjected to tax deduction. The researchers have investigated two things: 1)- the gradual impact of tax planning and earning management upon the informational content of the book income and the income that is subjected to tax deduction 2) - the relationship between relative registration of entries and the information content of book income the income that is subjected to tax deduction. Based on those two, it can be concluded that tax planning and quality of earnings have a major impact upon the information content of book income and the income that is subjected to tax deduction.

\section{The Balanced Scorecard System}

The process of assessing performance is considered as a major element in the processes of assessment. For instance, performance assessment is considered as a feedback process for the degree of the plan's effectiveness and it is also an indicator for the degree of performance in applying the proposed plan. It is agreed by accountants and administrators that the performance assessment is considered highly significant when planning and imposing control (Evans, 2005, p. 376).

In the past, the focus in the process of performance assessment used to be on the financial indicators mainly. However, later on, a need arose to have non-financial assessment tools. Such need arose due to the developments that have occurred in the sector of industry and due to the developments that have occurred in the field of management. The (Institute of Management Accountants) believed that it is necessary to find non-financial assessment tools that can be used along with the use of financial indicators and tools (Institute of Management Accountants, Statement $4 \mathrm{u}$, 1995, P. 10). The significance of performance assessment can be represented in the following points (Oak, 1995):

1) - Performance assessment has several impacts. The first impact is an organizational impact which is connected with measuring the performance of the management tools. This impact is also connected with the things that have been fulfilled from the proposed plan. As for the second impact, it is represented in the behavioral impact. Such impact is represented in the contributions made by people to implement the plan.

2) - Performance assessment seeks to evaluate of the effectiveness of the various administrative units. In addition, the significance of performance assessment also includes identifying the points of weakness and strength of these units. That is done in the aim of enhancing the identified points of strength and addressing the idenitified points of weakness.

3) - Tools of performance assessment play a significant role in modifying employees' behavior and emphasizing the activities that are highly significant to perform tasks.

4) - Performance assessment aims at identifying the management's liability for the results of the tasks it has performed. The significance of performance assessment is also represented in developing appropriate investment tools that can generate funds for the company.

5)-Performance assessment participates in conducting a self-assessment process that can participate in improving control upon all levels.

6) - Performance assessment seeks to adopt measures that can participate in developing the concepts of self - control and accountability.

7) - Performance assessment aims to assess skills, capabilities and competence of the employees who work in the organization. That is done to identify whether those skills and capabilities are appropriate or in need for further modification and renewal to make them more valuable.

8) - Performance assessment seeks to identify the impact of raising the number of units upon the organization's management, functions and activities which require expansion and development. 
9) - Performance assessment aims at continuing the process of distributing tasks upon divisions and individuals in accordance with results of the conducted performance assessment.

Kaplan \&Norton (1992) define the balanced scorecard system as being a system used as a guiding system for improving the financial and future performance and such improvement is done through proposing measures in the light of the following four dimensions:

(The financial dimension, customers' satisfaction, internal operations, and the dimension of learning and development).

Kaplan \&Norton (1998) define the balanced scorecard system as being as a tool used for translating the company's strategy and vision into objectives and measures that are based on four primary pillars. These pillars are:

(The financial dimension, customers' satisfaction, efficiency of the operational performance and the opportunities provided by the company for its employees, including the opportunities of learning and developing).

The balanced scorecard system has been receiving great attention by many companies and researchers. For instance, there was a study conducted in 2011 in USA that showed that $40 \%$ of one thousand (1000) companies have succeeded in applying this system. It was also concluded that local companies has been adopting this system in a constant manner. In addition, this system has become used much on the global level.

Atkinson et al. (2003) believe that the balanced scorecard system as being a system used for measuring performance in a regular ongoing manner. They believe that this system is also used to translate the company's strategy into clear objectives and measures that are appropriate to assess performance on the basis of certain performance standard. These performance standards are linked to a group of programs and tasks that should be performed and implemented to achieve these objectives.

Niven (2003) defines the balanced scorecard system as being a system used for measuring the performance of the facility which enables it to translate its strategy in a comprehensive manner through an efficient effective management. Chan (2004) defines the balanced scorecard system as being a system used for measuring performance and managing strategies.

Based on the aforementioned information, the balanced scorecard system can be defined as a comprehensive system used for measuring the organization's performance and such system is derived from the organization's visions and strategies. That is done through translating the organization's visions and strategies into standards and measures that can be easily understood by the employees. These standards and measures are proposed to be used later as a guide when conducting the organization's business and performing its tasks on its local level. This system takes the organization's financial and non-financial performance into consideration through proposing measures and standards that are based on the following dimensions: (customers' satisfaction, internal operational processes, and the opportunities provided by the company for its employees including the opportunities that are in relation to teaching and developing them).These measures and standards complement one another and are considered interconnected in a way that serves the organization's strategies and vision.

Based on the aforementioned information, the merits of the balanced scorecard system can be represented in the following (Rohm, 2002):

\section{1) - This system focus on achieving the strategic goals of the facility:}

This system is considered one of the most important tools of strategic management. For instance, this system makes the facility's strategic goals the main concern of every employee in the facility. Through adopting this system, the company can be guided and managed. In addition, it can translate the facility's strategies into acts. Through the system's four dimensions, management can control and follow up the facility's financial performance, promote employees 'capabilities and keep possession of then on-financial assets that are needed for achieving growth in the future. Hence, this system is considered as one of the most significant pillars that can participate in the achievement of success for the facility. In addition, this system provides the facility's managers with tools that are necessary and required for guiding the facility towards achieving success in the future. In addition, this system turns the facility's visions and strategies into standards and measurements. These measurements constitute an integrated measurement tool.

2)-This system provides the management with a feedback about the strategic performance and employees' performance

This process of feedback participates in the process of strategic learning. For instance, this process focuses on assessing the facility, its departments and employees to identify whether they are achieving the planned goals or not. 
The strategy being adopted is assessed on the basis of the current performance. Thus, it can be concluded that the balanced scorecard system can assist facilities in modifying the strategy being adopted to become more consistent with the changing circumstances.

\section{3)- This system reflects the status and performance of the organization's operations in a comprehensive} manner

This system is not only a system that assesses the facility's current operations. In fact, it is a system that identifies the new operations that must be conducted by the facility in order to maintain its success. This system takes creativity and operational processes into its consideration. Through merging those together, the system would be capable of providing the management with a group of tools that can reflect the status and performance of the organization's operations on the long term level (i.e. not just for the current time)

\section{4)- This system can keep the customers satisfied)-}

Keeping the current customer sand attracting new ones are things that are connected with fulfilling their needs and desires. For instance, achieving customers' satisfaction is considered to be an indicator for identifying the facility's efficiency and its success in achieving customers' satisfaction. Having a high facility's efficiency and much success in achieving customers' satisfaction can encourage the purchaser towards repeating the process of purchasing the facility's products or services.

\section{5)-Facilitating communication upon various administrative levels)}

This system participates in involving all the facility's employees in the facility's operations. That is done through providing each employee - in various administrative position -with an effective communication system that can participate in fulfilling customers' needs. Such communication system can encourage employees towards holding themselves accountable through conducting a comparison between the proposed goals and the actual results.

6)-This system participates in encouraging the organization towards making modifications and improvements in a constant manner)-

In order to enable the company to achieve an actual growth in the future, it must spend money and time in training its employees and developing their capabilities. That's why it is highly significant to develop and assess the employees' skills in a constant manner. Thus, it is significant to provide the facility with the tools needed to develop the external operations and improve the employee's skills.

\section{Dimensions of the Balanced Scorecard System}

The balanced scorecard system is based on four primary pillars. These pillars can appear in the figure No. (1) Below: (Michael Ritter, 2003, p. 47).

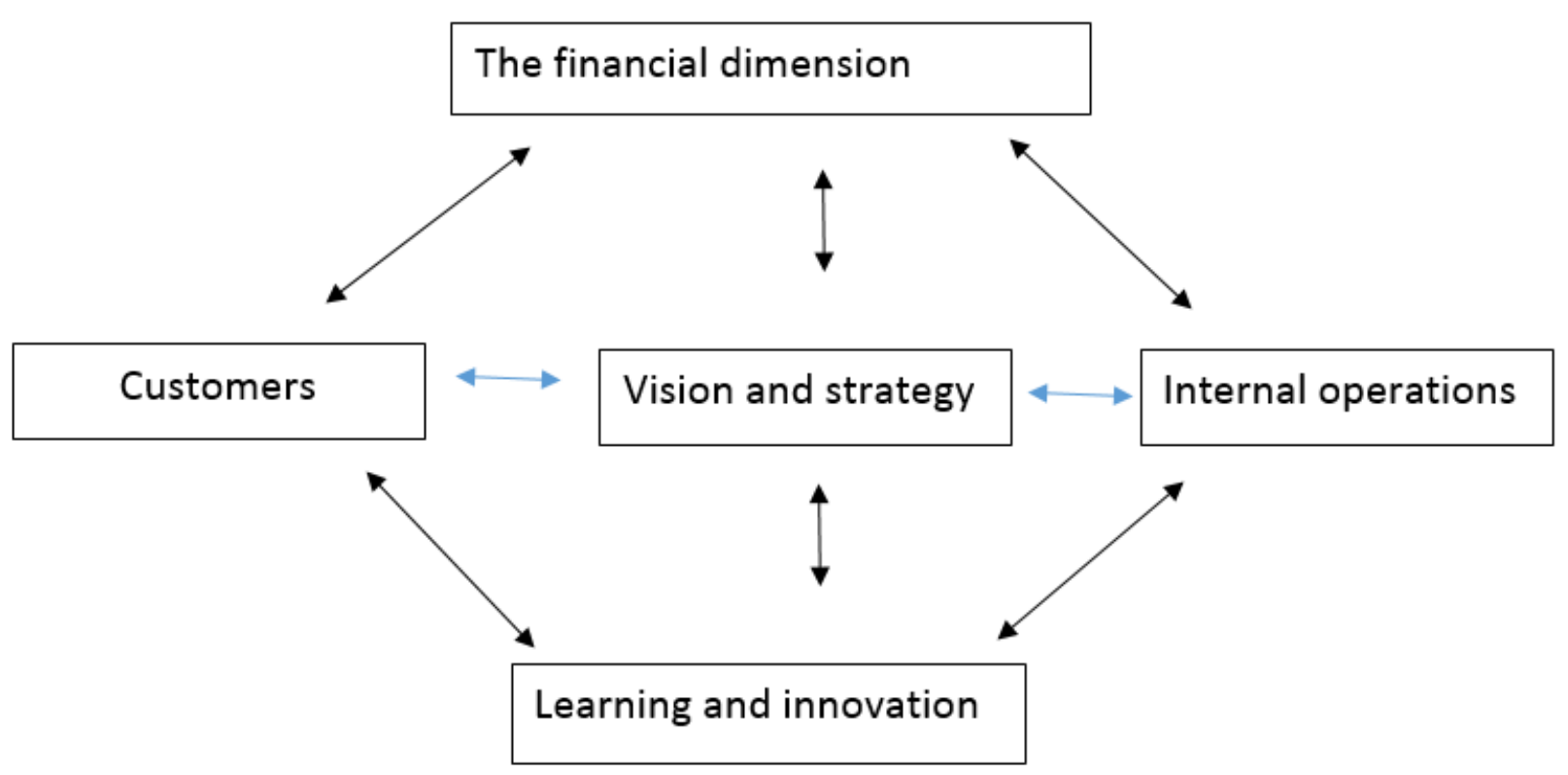

Figure 1 . The primary dimensions of the balanced scorecard system 


\section{These Dimensions shall be Illustrated below}

\subsection{The Financial Dimension}

Financial indicators are considered as a major element of the balanced scorecard system due to their significance and role in measuring and identifying the economic impacts of implementing the strategy. The financial dimension focuses on raising the institution's profits through reducing costs and raising more revenue. This dimension also focuses on promoting the factors that can participate in raising the institution's profits.

In general, the financial dimension aims at providing an answer for the following question: How should the institution be perceived by its owners and stakeholders?(Lawrie, 2004, p. 613 - 621)

The financial dimension is responsible for assessing the performance during the implementation of the project from various perspectives. It achieves that in a way that serves the information users who have financial interests to be gained from the institution. The information obtained through the financial dimension can participate in justifying the facility's financial decisions that are related to the relevant project.

\subsection{Customers' Dimension: (Kaplan and Atkinson, 1998, pp 551-557)}

This dimension is concerned with all the activities that can fulfill the needs and desires of the facility's customers. This dimension resolves around achieving customers' satisfaction, keeping the current ones, and attracting new ones. This dimension also resolves around preserving the organization's market share in the target markets and increasing the customer's profits.

In general, this dimension aims at providing answers for the following questions:

1) - How should be the organization be perceived by its current customers?

2) - How should the organization attract new customers?

3)-How should the organization fulfill customers' needs and desires and satisfy them to have them as loyal customers?

\subsection{Internal Operations Dimension: (Shulver \& Lawrie, 2000, p. 206-218)}

This dimension deals with all the internal operations which the company should excel at. These operations have a major impact upon achieving customers' satisfaction. For instance, such satisfaction can be achieved through excelling in the companies' operations in relation to their quality and the time needed to conduct them. Their satisfaction can be achieved through achieving an excellent financial position for the organization. In order to guarantee the success of this dimension, the organization must give attention to the following three phases)-

a) - The phase of innovation and development. This phase is concerned with developing the facility's products and services which can assist the facility in administering its products into new foreign markets and attracting new customers.

b) - The phase of operational processes. This phase includes all the processes which the product or service goes through starting from the moment of receiving the customers' requests until that service or product is submitted. However, these operational processes must be consistent with one another. In addition, the company's product or service must be delivered to the customer in the specified time.

c) - The phase of after - sale services. This phase is concerned with the services that the customers are provided with after the sale process. It includes maintenance and repair services and facilitating the process of payment and etc... (Cooper and Slagmnlder, 1997).

\subsection{The Dimension of Learning and Development}

This dimension is concerned with the skills and intellectual abilities of the company's employees. In the light of this dimension, it is believed that the organization's real investment is the investment conducted in human resources. Such investment is conducted through training and developing the facility's employees and helping them to acquire more knowledge and new skills. In the light of this dimension, the organization seeks to achieve agreement between the organization's goals and the employee's goals. That is done through achieving the long and short terms goals of the organization through achieving the employee's goals. In the light of this dimension, it is believed that the thoughts proposed by the senior management are not sufficient by themselves to develop the organization and lead it to success. In fact, those ideas must be supported by other ideas proposed by managers who are in lower managerial levels. That is because the managers who are holding lower managerial positions are in direct contact with the 
company's customers. In addition, they are the ones who deal with customers constantly and dealing with customers is one of the major factors that participate in achieving customers' satisfaction (Chen, 2006, p. $192-204$ ).

\section{Characteristics of the Study's Sample}

\section{1) - The educational level:}

The sample's educational level is presented in table No. (1) that is presented below:

\begin{tabular}{lll}
\hline Degree & Frequency & Percentage \% \\
\hline BA degree & 52 & $68.7 \%$ \\
\hline MA degree & 8 & $13.3 \%$ \\
\hline PhD degree & - & - \\
\hline Total & 60 & $100 \%$
\end{tabular}

It can be noticed that $68.7 \%$ of the respondents hold a bachelor (BA) degree and $13.3 \%$ of the study's respondents hold a master's degree.

\section{2)- Years of Experience}

\begin{tabular}{lll}
\hline Degree & Frequency & Percentage \% \\
\hline Less than five (5) years of experience & 33 & $55 \%$ \\
\hline $5-10$ years of experience & 16 & $26.7 \%$ \\
\hline $11-15$ years of experience & 11 & $18.3 \%$ \\
\hline Total & 60 & $100 \%$
\end{tabular}

It is noticed that $55 \%$ of the respondents possess experience that is less than 5 years and $26.7 \%$ of the respondents possess $(5-10)$ years of experience. Furthermore, $18.3 \%$ of the respondents possess $(11-15)$ years of experience

\section{Reliability Test}

Cronbach Alpha test was conducted to measure the reliability of study's instrument. The value of $a$ is (0.939) which is an excellent value because it far exceeds the accepted value (which is 0.60) (Malhotra, 2004)

\section{Hypotheses Test}

\section{Hypothesis(1):}

Ho : There is no impact for conducting tax planning in industrial public joint stock companies upon the performance of the Industrial companies listed in the Amman stock exchange market

Table (5)

Model Summary

\begin{tabular}{lllll}
\hline Model & R & R Square & Adjusted R Square Estimate \\
\hline 1 & $.963^{\mathrm{a}}$ & .927 & .926 & .19365
\end{tabular}

a. Predictors: (Constant), ind

\begin{tabular}{lllllll} 
ANOVA $^{\mathrm{b}}$ & & & & \\
\hline Model & & Sum of Squares & Df & Mean Square & F & Sig. \\
\hline 1 & Regression & 27.826 & 1 & 27.826 & 741.974 & $.000^{\mathrm{a}}$ \\
& Residual & 2.175 & 58 & .038 & & \\
& Total & 30.001 & 59 & & & \\
\end{tabular}

a. Predictors: (Constant), ind

b. Dependent Variable: dep 
Coefficients

\begin{tabular}{lllllll}
\hline \multirow{2}{*}{ Model } & & \multicolumn{3}{l}{ Unstandardized Coefficients } & \multicolumn{2}{l}{$\begin{array}{l}\text { Standardized } \\
\text { Coefficients }\end{array}$} \\
\cline { 2 - 6 } & & $\mathrm{B}$ & Std. Error & Beta & T & Sig. \\
\hline 1 & (Constant) & 1.548 & .097 & & 16.008 & .000 \\
\cline { 2 - 6 } & Ind & .688 & .025 & .963 & 27.239 & .000 \\
\hline
\end{tabular}

a. Dependent Variable: dep

The researchers conducted a linear regression test. Based on the aforementioned table, it can be noticed that the value of the calculated $t$ is (27.239) which is statistically significant at the significance level of (0.05). Thus, based on that, the aforementioned hypothesis is rejected. Thus, it can be concluded that there is an impact for conducting tax planning in industrial public joint stock companies upon the performance of the Industrial companies listed in the Amman stock exchange market.

\section{Hypothesis 2}

Ho)- There is no statistical significant difference between the respondents' attitudes towards the impact of tax planning in industrial public joint stock companies upon the performance of the Industrial companies listed in the Amman stock exchange market - which can be attributed to the variable of the educational level nor to the years of experience variable

Two-way ANOVA test was conducted to test the aforementioned hypothesis and the following results were concluded:

\begin{tabular}{llllll}
\hline \multicolumn{2}{l}{ Tests of Between-Subjects Effects } \\
\hline Dependent Variable: dep & & & \\
\hline Type III Sum of \\
Source & Squares & df & Mean Square & F & Sig. \\
\hline Corrected Model & $29.039^{\mathrm{a}}$ & 26 & 1.117 & 38.316 & .000 \\
\hline Intercept & 24.786 & 1 & 24.786 & 850.331 & .000 \\
\hline Ed level & .024 & 1 & .024 & .826 & .370 \\
\hline exper & .044 & 1 & .044 & 1.516 & .227 \\
\hline ind & 27.837 & 24 & 1.160 & 39.792 & .000 \\
\hline Error & .962 & 33 & .029 & & \\
\hline Total & 1034.505 & 60 & & & \\
\hline Corrected Total & 30.001 & 59 & & & \\
\hline
\end{tabular}

a. R Squared $=.968$ (Adjusted $\mathrm{R}$ Squared $=.943)$

Through the aforementioned table, it can be noticed that the calculated $\mathrm{f}$ value do not have any statistical significance at the significance level of (0.05). Thus, that means that there is no statistical significant difference between the respondents' attitudes towards the impact of tax planning in industrial public joint stock companies upon the performance of the Industrial companies listed in the Amman stock exchange market - which can be attributed to the variable of the educational level or to the years of experience variable.

\section{Conclusion}

The aim of the current study is represented in seeking to measure and identify the impact of tax planning in industrial public joint stock companies upon the performance of the Industrial companies listed in the Amman stock exchange market. 
The method of this study adopted the analytical descriptive approach the population of the current study includes financial managers who were working in Jordanian industrial public joint stock companies. The total number of those companies is 66 companies in Jordan.

Following are the main results:

1)-There is an impact for conducting tax planning in industrial public joint stock companies upon the performance of the Industrial companies listed in the Amman stock exchange market

2)-There is no statistical significant difference between the respondents' attitudes towards the impact of tax planning in industrial public joint stock companies upon the performance of the Industrial companies listed in the Amman stock exchange market - which can be attributed to the variable of the educational level or to the years of experience variable.

The researchers have proposed the following recommendations:

1) - Exert many efforts to raise awareness of companies' managers and employees about the legal consequences of tax evasion.

2)- Exert much efforts to raise awareness of companies' managers and employees - in various sectors -about matters related to taxes

3) - Investigate the various factors that participate in making the company incapable to pay its taxes and proposing several solutions for addressing those factors.

4) Future studies are suggested upon other economic sectors.

\section{References}

Aghdaie, S. F. A., Seidi, M., \& Riasi, A. (2012). Identifying the barriers to Iran's Saffron export by using Porter's diamond model. International journal of marketing studies, 4(5), 129-138.

Ahmad, Abed Al-Rahim. (2001). the impact of tax planning upon reducing the tax burden imposed upon the profits of industrial joint stock companies in Yemen.

Ansari, A., \& Riasi, A. (2016). Modeling and evaluating customer loyalty using neural networks: Evidence from startup insurance companies. Future Business Journal, 2(1), 15-30.

Checherita-Westphal, C., \& Rother, P. (2012). The impact of high government debt on economic growth and its channels: An empirical investigation for the euro area. European Economic Review, 56(7), 1392-1405. https://doi.org/10.1016/j.euroecorev.2012.06.007

Chen, L. \& Dhaliwal, D. \& Trombley, M. (2007). The Impact of Earnings Management and Tax Planning on the Information Content of Earnings, Electronic copy available at: http://ssrn.com/abstract=1028808.

Christopher S. Armstrong, Jennifer L. Blouin, David F. Larcker. (2012). The incentives for tax planning. Journal of Accounting and Economics, 53(1-2), February-April 2012, 391-411. https://doi.org/10.1016/j.jacceco.2011.04.001

Daheya, Abdullah Adan Khamis. (2010). the impact of strategic planning upon the tax performance in Sudan during the period (1995 - 2005), PhD dissertation. Sudan University of Science and Technology.

Edwards, A., Schwab, C., \& T. Shevlin. (2013). Financial Constraints and the Incentives for Tax Planning, 2013 American Taxation Association Midyear Meeting. Available at SSRN: http://ssrn.com/abstract=2216875

Ibrahim, Nabil. (2012). A proposed model to measure the impact of tax planning upon the financial performance of joint stock companies listed in the Egyptian financial market (A field empirical study). A study submitted to the conference of the Egyptian tax association that was held on $16^{\text {th }}$ and $17^{\text {th }}$, September, 2012 titled as "the future tax system and its impact upon economy and investment".

Kawor, S. \& Kportorgbi, H. (2014). Effect of Tax Planning on Firms Market Performance: Evidence from Listed Firms in Ghana. International Journal of Economics and Finance, 6(3), 162-168. https://doi.org/10.5539/ijef.v6n3p162

Khaoula A. \& Ali,Z. (2012). The board of directors and the corporate tax planning: Empirical Evidence from Tunisia. International Journal of Accounting and Financial Reporting, 2(2), 142-157. https://doi.org/10.5296/ijafr.v2i2.2525 
Khwaira, Mahfouz. (2004). Tax planning in the companies listed in the Palestinian stock exchange market (A field study). MA thesis. Al-Najah National University.

Nor Shaipah Abdul Wahab, Kevin Holland. (2012). Tax planning, corporate governance and equity value. The British Accounting Review, 44(2), June 2012, 111-124. https://doi.org/10.1016/j.bar.2012.03.005

Riasi, A. (2015). Competitive Advantages of Shadow Banking Industry: An Analysis Using Porter Diamond Model. Business Management and Strategy, 6(2), 15-27. https://doi.org/10.5296/bms.v6i2.8334

ZARAI , M. (2013). Corporate Tax Planning and Debt Endogeneity: Case of American Firms. International Journal of Business and Commerce, 3(3), 42-53.

\section{Notes}

Note 1. Weinstein, Mark, "Individual \& Business Tax Planning Libraries" CPA Technology Advisor, 15. 7 (Nov 2005):

Note 2. Harvey M. Silets, Michael C. Drew, "Offshore Asset Protection Trusts: Tax Planning or Tax Fraud?" Journal of Money Laundering Control Volume: 5 Issue: 12001.

Note 3. Ahmed Riahi-Belkaoui "Relationship between tax compliance internationally and selected determinants of tax morale" Journal of International Accounting, Auditing and Taxation, Volume 13, Issue 2, 2004, Pages 135-143.

Note 4. Williams, Michael G; Hughes, John S; Levine, Carolyn B.” Influence of Capital Gains Tax Policy on Credibility of Unverified Disclosures" The Accounting Review85. 2(Mar 2010): 719-743.

Note 5. Bashar H. Malkawi, Haitham A. Haloush, "The case of income tax evasion in Jordan: symptoms and solutions" Journal of Financial Crime Volume: 15 Issue: 32008 